\title{
Sequence polymorphism-based identification and quantification of Vibrio nigripulchritudo at the species and subspecies level targeting an emerging pathogen for cultured shrimp in New Caledonia
}

\author{
Cyrille Goarant ${ }^{a},{ }^{b,}$, Yann Reynaud ${ }^{b, c}$, Dominique Ansquer ${ }^{b}$, Sophie de Decker $^{b}$ and Fabrice Merien ${ }^{a}$ \\ a Laboratoire de Recherche en Bactériologie, Institut Pasteur de Nouvelle Calédonie, Noumea, New Caledonia \\ ${ }^{\mathrm{b}}$ IFREMER, Département Aquaculture en Nouvelle-Calédonie, Noumea, New Caledonia \\ ${ }^{c}$ IFREMER, Département Génétique et Pathologie, La Tremblade, France \\ *: to whom correspondence should be sent : \\ Laboratoire de Recherche en Bactériologie, Institut Pasteur of New Caledonia, BP 61, 98845 Noumea cedex, \\ New Caledonia. cgoarant@ifremer.fr
}

\begin{abstract}
:
In a previous study, we demonstrated the existence of an emerging cluster of Vibrio nigripulchritudo that proved to be associated with shrimp mortality events in New Caledonia. Using sequence polymorphisms evidenced in this previous MultiLocus Sequence Typing study, we developed two new quantitative PCR assays permitting the detection and quantification of $\mathrm{V}$. nigripulchritudo at the genospecies level using SYBR Green I chemistry and at the emerging cluster level using Fluorescence Resonance Energy Transfer technology with hybridization probes.

The use of this molecular diagnostic tool evidenced the colonization of the shrimp pond ecosystem by the pathogenic cluster at least at the onset of the disease. This new tool will allow better investigation of the dynamics of this bacterial pathogen in the shrimp farm ecosystem.
\end{abstract}

Keywords: Real-time PCR; Mariculture; Pathogen; Vibrio; Cluster-specific; Shrimp 


\section{Introduction:}

Vibrio species are widely distributed bacteria that colonize aquatic habitats, and are notably present in and around mariculture facilities. Vibriosis, diseases caused by Vibrio species, are known to be major disease problems in farmed marine animals, including penaeid shrimp, in which they have been recognized as potential pathogens since the beginning of shrimp farming activities (Lightner and Lewis, 1975 ; Bondad-Reantaso et al., 2005). However, diagnostic tools allowing to study vibriosis in shrimp have seldom been developed. Conventional laboratory methods based on bacterial culture and isolation from the shrimp or its environment demand the use of suitable culture media and subsequent identification. Moreover, they are time-consuming and require several days to obtain confirmatory results. Additionally, the concept of "infective dose" is of particular concern in Vibrio infections (Lobnitz et al., 2000), and was notably confirmed in shrimp vibriosis (Saulnier et al., 2000). Therefore, the development of reliable, quantitative and sensitive methods for the detection of bacterial shrimp pathogens is essential both for research studies or to conceive and control sanitization practices.

Conventional polymerase chain reaction (PCR) method had the potential to make a dramatic impact in diagnosing infectious diseases. More recently, the use of real time PCR has made the detection and quantification of bacteria much more rapid and was successfully applied to a number of Vibrio species (Blackstone et al., 2003 ; Panicker et al., 2004) including shrimp pathogens (Goarant and Mérien, 2006).

Additionally, it is recognized that strains belonging to the same Vibrio species can have different virulence patterns to shrimp (Oakey and Owens, 2000 ; Hernandez and Olmos, 2004 ; Goarant et al., 2006a). However the knowledge of the pathophysiology of vibriosis in shrimp remains limited and little is known concerning virulence factors in Vibrio that are pathogenic to shrimp. As a consequence, there is frequently a lack of genomic data that would enable the development of relevant molecular tools able to discriminate between different genotypes within a Vibrio species. Very few of these have recently been developed in the field of shrimp pathology but still require culture and isolation of the targeted organism (Hernandez and Olmos, 2004).

In the recent years, there is increased access to high throughput sequencing throughout the world and MultiLocus Sequence Typing (MLST) is becoming a standard for epidemiological studies (Feil and Enright, 2004 ; Cooper and Feil, 2004 ; Hall and Barlow, 2006). As a result, there is increased opportunity to gain access to epidemiologically relevant sequencing data providing the basis for the design of relevant diagnostic tools. For instance, cluster-specific sequencing data were successfully used to design a PCR assay targeting a regional variant of Vibrio sp. associated with shrimp disease (Rañoa and Hedreyda, 2005).

New Caledonia is located in the South Pacific between latitudes $19^{\circ} \mathrm{S}$ and $23^{\circ} \mathrm{S}$ and has a tropical oceanic climate. Its shrimp industry is a small but growing industry that benefits from an almost virus-free status. However, New Caledonian shrimp farming has been affected since 1993 by a cool season vibriosis named Syndrome 93 and causing high mortalities in juvenile shrimp (Mermoud et al., 1998). This disease was shown to be caused by Vibrio penaeicida but also implicated a few other Vibrio strains including V. nigripulchritudo (Costa et al., 1998). These pathogenic V. nigripulchritudo strains were geographically restricted to two adjoining farms within one bay (Goarant et al., 1999). However V. nigripulchritudo was later isolated in December 1997 from an outbreak of a new disease in one farm located $50 \mathrm{~km}$ south of the original isolation. First diagnosed in one farm, the organism was also causing a systemic vibriosis, but in high temperature conditions that did not fit the classical Syndrome 93 epidemiology, which typically occurs at low water temperatures. This new disease, named "Summer Syndrome" has affected all summer crops on this farm ever since and since 2002, affected a new farm built close to the affected one (Goarant et al., 2006a). Currently, 
another neighbouring farm is also suspecting the onset of this disease. Experimental infections together with a molecular typing study revealed that both pathogenic and nonpathogenic $V$. nigripulchritudo strains co-existed in a single shrimp farm environment and that the disease, named "summer syndrome" was caused by a single, possibly emerging cluster of virulent strains (Goarant et al., 2006a ; Goarant et al., 2006b). The facts that (i) $V$. nigripulchritudo is associated with two distinct shrimp diseases and (ii) that one of these ("Summer Syndrome") is possibly emergent highlight the need for a relevant diagnostic tool targeting the emerging cluster of pathogenic strains.

Emerging infectious diseases in marine ecosystems are recognized to be on the rise, though it is also recognized that little progress has been made in identifying the causative agents (Harvell et al., 1999). Regarding this issue, PCR and more recently real-time PCR assays have allowed highly specific tools that have proven very powerful. Here we describe the development and optimization of a real time PCR assay using SYBR Green I chemistry for the rapid identification and quantification of $V$. nigripulchritudo at the genospecies level and using the FRET technology with the hybridization probe (HybProbe ${ }^{\circledR}$ ) format (see Espy et al., 2006 for review) for specific distinction and quantification of strains from this emerging pathogenic cluster, both on the LightCycler platform.

\section{Material and methods}

\section{Bacterial strains and DNAs:}

Both the type strain and wild-type isolates of Vibrio nigripulchritudo were used in this study. V. nigripulchritudo CIP $103192^{\top}$ (ATCC 27043) was provided by Collection de I'Institut Pasteur, Paris, France. Twenty three wild-type isolates, from both clinical and environmental origins, isolated between May 1995 and October 2003 in different farms and hatcheries of the New Caledonian West Coast were included in this study (Table 1). The origin, identification and virulence of these $V$. nigripulchritudo isolates towards healthy Litopenaeus stylirostris were reported previously (Goarant et al., 2006a) (see table 1). All 23 strains are deposited in the bacterial collection of the CRB (Centre de Ressources Biologiques, Laboratoire de Génétique et Pathologie, Institut Français de Recherche pour l'Exploitation de la MER (IFREMER), La Tremblade, France).

To assess the specificity of our real-time assays, we used a panel of strains from other Vibrio species ( $V$. penaeicida $\mathrm{KH}-1^{\top}$ from Japan, $V$. penaeicida AM101 from New Caledonia $V$. alginolyticus, $V$. harveyi, V. nigripulchritudo, V. aesturianus, V. tubiashii, $V$. damsela, $V$. orientalis, $V$. splendidus, $V$. fluvialis and $V$. nereis). Bacterial strains other than members of the genus Vibrio (Proteus mirabilis, Klebsiella pneumoniae, Escherichia coli, Staphylococcus aureus, Streptococcus agalactiae, Acinetobacter baumanni, Shigella flexneri, Salmonella sp.) were also used for specificity tests. All strains were subcultured in adequate media and their respective genomic DNA were extracted and purified as described by Brenner et al. (1999).

\section{Sequence data, primers and probe design:}

The sequences of six genes ( $r r s$, toxR, gyrB, rpoD, rctB and recA) were determined previously as part of a molecular typing study for all $V$. nigripulchritudo strains (Goarant et al., 2006b). Vibrio nigripulchritudo sequences from all six genes were aligned with BioEdit ${ }^{\circledR}$ (Hall, 1999) using CLUSTAL W (Thompson et al, 1994) and phylogenetic trees were built using Phylo-win program (Galtier et al., 1996) applied to Neighbour Joining method and Kimura's 2-parameter distances (Gascuel, 1987). Reliability of topologies was assessed by the bootstrap method with 1000 replicates.

Twenty eight Vibrio spp. gyrB sequences retrieved from GenBank were aligned together with 24 V. nigripulchritudo sequences (Goarant et al., 2006b) using BioEdit ${ }^{\circ}$ (Hall, 1999). Primers specific for $V$. nigripulchritudo (genospecies) and probes specific for the 
emerging cluster were deducted from this alignment. Primers VngF2 (CCCGAACGAAGCGAAA) and VngR2 (ACCTTTCAGTGGCAAGATG) and probes specific of the emerging cluster VngA1 (TGTGGAGGGTGACTCTGC-Fluorescein) and VngS1 (Red705-CCCAGCACTCTCTGAACTCTAT-Phosphate) were designed using the LightCycler Probe Design software 2.0 (Roche Applied Science) and synthetized by Proligo Singapore Pty Ltd (Biopolis way, Singapore). All primers and probes sequences were checked online against the NCBI genomic database GenBank to verify their specificity for their intended target.

\section{Real time PCR reactions and optimization:}

The LightCycler FastStart DNA Master PLUS SYBR Green I kit (Roche Applied Science, Auckland, New Zealand) was used as the basis for the reaction mixtures, using a $20 \mu \mathrm{l}$ volume in each reaction capillary. Primers VngF2 and VngR2 were used at $0.5 \mu \mathrm{M}$ and the reaction optimized for specificity. The LightCycler FastStart DNA Master PLUS Hybridisation Probe kit (Roche Applied Science) was used with the hybridization probes VngA1 and VngS1 in conjunction with the VngF2 and VngR2 primers and the reaction optimized for optimal signal to noise ratio by testing $0.1,0.2$ and $0.4 \mu \mathrm{M}$ each probe. After distributing $15 \mu \mathrm{l}$ aliquots of the master mix among the capillaries, $5 \mu \mathrm{l}$ of a DNA extract was added before the capillaries were capped, centrifuged and placed in the LightCycler 2.0 sample carousel. A negative control with PCR-grade water rather than template DNA was always used with the samples. Aerosol-barrier pipette tips were used throughout the procedure. The PCR conditions were optimized by testing various annealing temperatures (from 57 to $63^{\circ} \mathrm{C}$ ) and durations (from 2 to 5 seconds) and elongation duration (10, 12 or 15 seconds). Amplification conditions involved a pre-incubation at $95^{\circ} \mathrm{C}$ for $10 \mathrm{~min}$ (FastStart Taq DNA polymerase activation) followed by amplification of the target DNA for 45 (50 for the probe-based assay) cycles of $95^{\circ} \mathrm{C}$ for 5 seconds, $62^{\circ} \mathrm{C}$ or $60^{\circ} \mathrm{C}$ for 3 seconds (for SYBR Green I assay or hybridization probe assay respectively) and $72^{\circ} \mathrm{C}$ for 12 seconds using a transition rate of $20^{\circ} \mathrm{C} /$ second between all steps. Melting curve analysis was performed subsequently at a linear temperature transition rate of $0.1^{\circ} \mathrm{C} / \mathrm{sec}$ from $65^{\circ} \mathrm{C}$ to $95^{\circ} \mathrm{C}$ with continuous fluorescence acquisition. This step was followed by a cooling step at $40^{\circ} \mathrm{C}$ for $30 \mathrm{sec}$. The first derivative of the initial melting curve (-dF/dT) was automatically plotted against temperature for improved determination of the melting temperature $\left(T_{\mathrm{m}}\right)$. All experiments were repeated at least twice for reproducibility.

\section{Standard curves:}

The amplified 258 bp product was loaded on a 1.5\% agarose gel stained with ethidium bromide and electrophoresed for 40 minutes at $15 \mathrm{~V} . \mathrm{cm}^{-1}$. The amplicon was then sliced from the gel under UV illumination and purified using the MinElute Gel Extraction kit (Qiagen, Doncaster, Victoria, Australia). The copy number of this extract was determined by spectrophotometer (Eppendorf BioPhotometer) and conversion based on amplicon size (Overbergh et al., 2003). Serial dilutions of the amplicon from 7.2 to $7.2 \times$ $10^{8}$ gene copies per reaction were then amplified in triplicates in order to obtain the standard curves. One standard curve was then calculated for each assay (SYBR Green I and Hybridization Probes) using LightCycler Software 4.0 (Roche Applied Science) and validated according to established parameters.

\section{Validation with field samples:}

In order to validate these assays, samples were taken from a pond in a farm affected by the Summer Syndrome. The inlet channel, the growout pond (pond water and sediment pore water at two different locations in the pond) and the outlet channel were sampled 
weekly for 5 weeks resulting in 25 environmental field samples and processed as described previously (Goarant and Mérien, 2006) from one week before a mortality outbreak. Moribund shrimp specimens were used to confirm the etiological agent of this mortality outbreak. The mortality data, kindly provided by the farm's staff, is presented as the total daily number of dead and moribund shrimp found on the pond edges.

\section{Results}

Choice of target gene, primers and probes design:

Out of the six genes studied, five permitted to clearly discriminate the emerging cluster from other $V$. nigripulchritudo strains. Of these, gyrB was considered the best target choice according to its discriminating potential, as shown on the dendrogram in Figure 1. Additionally, the corresponding nucleotide sequence displayed 3 point mutations within a 16 bp region where a cluster-specific probe pair could be designed. The Sensor probe was designed to overlap these mutations, the Anchor probe being designed over a conserved flanking region (Figure 2). Forward and reverse primers were chosen within regions being conserved in all $V$. nigripulchritudo but variable over the genus Vibrio. Over the possible primers, only the ones displaying at least two mismatches for the other Vibrio species were considered.

\section{Specificity:}

The specificity of both assays (using SYBR Green I or hybridization probe format) was assessed using DNAs from a selection of $V$. nigripulchritudo (see table 1 ) and a variety of Vibrio spp. and non-Vibrio isolates, as listed in the Material and Methods section. All $V$. nigripulchritudo strains yielded the single expected 258 bp amplicon, confirmed by agarose gel electrophoresis. None of the non- $V$. nigripulchritudo strains gave any detectable amplicon when the run was as follows: 45 cycles of $95^{\circ} \mathrm{C}$ for $5 \mathrm{sec}, 62^{\circ} \mathrm{C}$ for $3 \mathrm{sec}$ and $72^{\circ} \mathrm{C}$ for $12 \mathrm{sec}$, which was determined to be the optimal condition for SYBR Green I quantification at the species level. When using hybridization probes, only the strains belonging to the emerging pathogenic cluster of $V$. nigripulchritudo produced fluorescence by FRET technology when the run was as follow: 45 cycles including $95^{\circ} \mathrm{C}$ for $5 \mathrm{sec}, 60^{\circ} \mathrm{C}$ for $3 \mathrm{sec}$ and $72^{\circ} \mathrm{C}$ for $12 \mathrm{sec}$, whereas the expected $258 \mathrm{bp}$ amplicon could be detected on agarose gel for all $V$. nigripulchritudo strains, but not detected by the hybridization probe format, because of sequence polymorphism preventing the hybridization of the sensor VngS1 probe.

\section{Genotypes and melting temperatures:}

The melting curves were obtained by denaturing the amplicon at the end of the amplification step after a SYBR Green I run. Melting temperatures of the amplicons obtained from the emerging cluster were in the range [87.5 - 87.8] ${ }^{\circ} \mathrm{C}$, from the type strain $88.2^{\circ} \mathrm{C}$, and all other $V$. nigripulchritudo isolates in the range $[88.4-89.1]^{\circ} \mathrm{C}$. Unfortunately, the proximity of the type strain's $T_{\mathrm{m}}$ did not permit to distinguish with certainty this strain from the emerging cluster. However, this should permit excluding the emerging genotype when $T_{\mathrm{m}}$ is over $88.3^{\circ} \mathrm{C}\left(+0.5^{\circ} \mathrm{C}\right)$ when using this SYBR Green I PCR assay with clonal samples, e.g. purified DNA from an unknown strain (Figure $3 \mathrm{~b}$ ). When amplifying mixed populations of both the emerging cluster and other strains (so as to reflect the diversity possibly seen in environmental samples), the $T_{\mathrm{m}}$ shift between the emerging cluster's and the other strains was not sufficient to enable the distinction of a 2-peak shape of the melting peak curve (Figure $3 \mathrm{c}$ ).

\section{Standard curves and quantification in environmental samples:}

The standard curves obtained using the SYBR Green I and the hybridization probe assays are shown in Figure 4. The detection limit was estimated using standard 
LightCycler software parameters to be of 20 gene copies per capillary for the SYBR Green I assay (after 45 cycles) and 5 gene copies per capillary for the hybridization probe format (50 cycles).

Moribund shrimp samples from the affected farm confirmed that the observed mortality was actually caused by the typical Summer Syndrome and that a highly pathogenic $V$. nigripulchritudo from the emerging cluster was the etiological agent involved as previously described (Goarant et al., 2006a). Using environmental samples taken from this affected pond, V. nigripulchritudo belonging to the emerging cluster could be evidenced from the sediment pore waters and pond water during and after the mortality outbreak. Using the SYBR Green I assay, the species V. nigripulchritudo could be detected from the water and the sediment pore water but seldom from the outlet channel. The same samples studied with the hybridization probe assay demonstrated that the emerging cluster could be found in these samples from the onset of the disease. V. nigripulchritudo from the emerging cluster were found in pond water $\left(4 \times 10^{4}\right.$ $\left.\mathrm{ml}^{-1}\right)$ and the sediment pore water at two locations in the pond $\left(400 \mathrm{ml}^{-1}\right.$ in one point and $1100 \mathrm{ml}^{-1}$ in the other point) on the day the first moribund shrimp was observed and until the last but one sample, corresponding to the end of the mortality outbreak (Figure 5). Interestingly, it was detected only once and at a relatively low concentration from the outlet channel ( $250 \mathrm{ml}^{-1}$ with the same assumption). The last samples, taken one week after the end of this outbreak, tested all negative. During this 5-week survey, all samples from the pumping (renewal) water tested negative with either assay.

\section{Discussion:}

Vibriosis has been a major problem in shrimp farming since the beginning of this activity. However, diagnostic tools have only recently been developed (Hernandez and Olmos, 2004 ; Rañoa and Hedreyda, 2005) because researchers have often lacked the necessary knowledge to design relevant infra-specific molecular tools.

Increased access to high throughput sequencing platforms has made MLST a typing reference technique for epidemiology in the recent years (Enright and Spratt, 1999 ; Urwin and Maiden, 2003 ; Cooper and Feil, 2004 ; Hall and Barlow, 2006) and has also been used in Vibrio (Kotetishvili et al., 2003 ; O'Shea et al., 2004 ; Goarant et al., 2006b ; Lee et al., 2006). As a result, there is increased knowledge on group-specific sequences variations linked to epidemiologically significant data, providing a way to gain access to infra-specific molecular tools to study these complex pathologies.

Hybridization probes using FRET technology provide a tool to study sequence polymorphisms within an amplicon (see Espy et al (2006) for review). A single nucleotide mismatch in the target of a sensor probe will result in a variation of annealing strength between the amplicon and the corresponding probe, resulting in a lower melting temperature of the probe system. More than two or three mismatches will abolish the FRET by preventing probe binding using an adequate annealing temperature. This technology is of particular interest and has often been used for intraspecific discrimination in both bacteria and viruses (Whalley et al., 2001 ; Hiratsuka et al., 2002 ; Vernel-Pauillac et al., 2006).

Since 1997 shrimp aquaculture in New Caledonia has been affected by a seasonal vibriosis inducing heavy mortality in two neighbouring farms. Experimental pathology and molecular epidemiology studies demonstrated that this new disease is caused by a single emerging cluster of virulent strains (Goarant et al., 2006b). Using sequences derived from a MLST approach, we show that this cluster could be characterized by 3 point mutations on the gyrB gene, close enough to be covered by a single probe. These mutations appear stable enough to be used as a basis of our diagnostic tool, being conserved over our strain selection that covers 6 farms and more than 3 years (see Table 1). Using these mutations, we successfully developed a quantitative PCR assay 
on the LightCycler platform targeting this emerging shrimp pathogenic cluster within the genospecies $V$. nigripulchritudo. Using a species-specific primer set and adequate stringency, this assay allows the quantification of $V$. nigripulchritudo at the species level using SYBR Green I chemistry. Using a pair of hybridization probes targeting clusterspecific mutations and other optimized stringency conditions, this assay permits the detection and quantification of a particular cluster at the sub-species level.

The gene gyrB being single-copied in Vibrio genomes, absolute quantification corresponds to bacterial quantification. Therefore, we constructed our standard curve based on gene copies derived from spectrophotometric readings of a PCR product and calculation of copy numbers (Overbergh et al., 2003). It must be noted that the exact yield of the extraction process from samples must be lower than 1 and therefore the concentration evaluated with our assay when used with field samples is most probably somewhat under-estimated. A standard curve could be designed using samples of known concentrations treated with the same extraction process as the study samples as described previously (Goarant and Mérien, 2006).

This assay was used with environmental samples from a pond affected in 2006 by the "summer syndrome" disease, confirming (by a molecular method) the colonization of the shrimp pond ecosystem by the pathogenic cluster at least at the onset of the disease. Additionally, this result confirms that the targeted mutations are stable over time, being found again 6 years after the first isolation of this emerging pathogenic strain. Interestingly, the pathogen was seldom found in the outlet channel, even during the mortality outbreak that most probably results in the production of large numbers of pathogens. Considering the dilution factors of the water discharged from the farm, the follow up of the pathogens in the farm's surrounding environment would necessitate the extraction of bacterial DNA from much larger volumes of seawater, at least in the range of milliliters. This point still has to be studied before using this tool for such a purpose. DNA extraction techniques from large environmental samples have been compared and described by some authors (Boström et al., 2004 ; Mumy and Findlay, 2004) and must be tested with our samples, formerly demonstrated to contain PCR inhibitors (Goarant and Mérien, 2006). For such a survey or for sanitation purpose, an adequate sampling strategy must also be decided, given the very wide volumes to be considered. As an indication, shrimp ponds in New Caledonia are in the range 1-11 hectares with an average 1 meter depth.

Current studies aim at developing molecular tools targeting virulence genes, that would prove even more useful but need longer studies to be conducted. When successfully developed, they will not only permit to study virulence expression but also to evaluate the presence of these virulence genes in other species of the bacterioplankton, virulence genes being frequently mobile genetic elements (Dobrindt and Hacker, 2001 ; Burrus and Waldor, 2004).

\section{Acknowledgments}

This work was partly supported by grants from the South and North Provinces of New Caledonia, Ifremer and the French Ministry of Research. YR benefits from a PhD grant from Ifremer and the Government of New Caledonia. FM was supported by the International Network of Pasteur Institutes. Thanks are due to F. Vernel-Pauillac and to J.F. Mackay for helpful comments and technical hints and tips. 


\section{References:}

Blackstone, G.M., Nordstrom, J.L., Vickery, M.C., Bowen, M.D., Meyer, R.F., DePaola, A., 2003. Detection of pathogenic Vibrio parahaemolyticus in oyster enrichments by real time PCR. J. Microbiol. Methods. 53, 149-155.

Bondad-Reantaso, M.G., Subasinghe, R.P., Arthur, J.R., Ogawa, K., Chinabut, S., Adlard, R., Tan, Z., Shariff, M., 2005. Disease and health management in Asian aquaculture. Vet. Parasitol. 132, 249-272.

Boström, K.H., Simu, K., Hagström, Å., Riemann, L., 2004. Optimization of DNA extraction for quantitative marine bacterioplankton community analysis. Limnol. Oceanogr. Meth. 2, 365-373.

Brenner, D.J., Kaufmann, A.F., Sulzer, K.R., Steigerwalt, A.G., Rogers, F.C., Weyant, R.S., 1999. Further determination of DNA relatedness between serogroups and serovars in the family Leptospiraceae with a proposal for Leptospira alexanderi sp. nov. and four new Leptospira genomospecies. Int. J. Syst. Bacteriol. 49, 839858.

Burrus, V., Waldor, M.K., 2004. Shaping bacterial genomes with integrative and conjugative elements. Res. Microbiol. 155, 376-386.

Cooper, J.E., Feil, E.J., 2004. Multilocus sequence typing - what is resolved? Trends Microbiol. 12, 373-377.

Costa, R., Mermoud, I., Koblavi, S., Morlet, B., Haffner, P., Berthe, F., Le Groumellec, M., Grimont, P., 1998. Isolation and characterization of bacteria associated with a Penaeus stylirostris disease (Syndrome 93) in New Caledonia, Aquaculture. 164, 297-309.

Dobrindt, U., Hacker, J., 2001. Whole genome plasticity in pathogenic bacteria. Curr. Opin. Microbiol. 4, 550-557.

Enright, M.C., Spratt, B.G., 1999. Multilocus sequence typing. Trends Microbiol. 7, 482-487.

Espy, M.J., Uhl, J.R., Sloan, L.M., Buckwalter, S.P., Jones, M.F., Vetter, E.A., Yao, J.D.C., Wengenack, N.L. Rosenblatt, J.E. Cockerill, III, F.R., Smith, T.F., 2006. RealTime PCR in Clinical Microbiology: Applications for Routine Laboratory Testing. Clin. Microbiol. Rev. 19, 165-256.

Feil, E.J., Enright, M.C., 2004. Analyses of clonality and the evolution of bacterial pathogens. Curr. Opin. Microbiol. 7, 308-313.

Galtier, N., Gouy, M., Gautier, C., 1996. Seaview and Phylo_win, two graphic tools for sequence alignment and molecular phylogeny. Comput. Appl. Biosci. 12, 543548.

Gascuel, O., 1987. BIONJ: an improved version of the NJ algorithm based on a simple model of sequence data. Mol. Biol. Evol. 14,685-695.

Goarant, C., Mérien, F., 2006. Quantification of Vibrio penaeicida, the etiological agent of Syndrome 93 in New Caledonian shrimp, by real-timePCR using SYBR Green I chemistry. J. Microbiol. Methods. 67, 27-35. 
Goarant, C., Ansquer, D., Herlin, J., Domalain, D., Imbert, F., De Decker, S., 2006a. "Summer Syndrome" in Litopenaeus stylirostris in New Caledonia: Pathology and epidemiology of the etiological agent, Vibrio nigripulchritudo. Aquaculture. 253, 105113.

Goarant, C., Mérien, F., Berthe, F., Mermoud, I., Pérolat, P., 1999. Arbitrarily primed PCR to type Vibrio spp. pathogenic for shrimp, Appl. Environ. Microbiol. 65, 11451151.

Goarant, C., Reynaud, Y., Ansquer, D., De Decker, S., Saulnier, D., Le Roux, F., 2006b. Molecular epidemiology of Vibrio nigripulchritudo, a pathogen of cultured penaeid shrimp (Litopenaeus stylirostris) in New Caledonia. Syst. Appl. Microbiol. $29,570-580$.

Hall, B.G., Barlow, M., 2006. Phylogenetic analysis as a tool in molecular epidemiology of infectious diseases. Ann. Epidemiol. 16, 157-169.

Hall, T.A. 1999. BioEdit: a user-friendly biological sequence alignment editor and analysis program for Windows 95/98/NT. Nucleic Acids Symp. Ser. 41, 95-98.

Harvell, C.D., Kim, K., Burkholder, J.M., Colwell, R.R., Epstein, P.R., Grimes, D.J., Hofmann, E.E., Lipp, E.K., Osterhaus, A.D.M.E., Overstreet, R.M., Porter, J.W., Smith, G.W., Vasta, G.R., 1999. Emerging Marine Diseases - Climate Links and Anthropogenic Factors. Science. 285, 1505-1510.

Hernandez, G., Olmos, J., 2004. Molecular identification of pathogenic and nonpathogenic strains of Vibrio harveyi using PCR and RAPD. Appl. Microbiol. Biotechnol. 63, 722-727.

Hiratsuka, M., Narahara, K., Kishikawa, Y., Hamdy, S.I., Endo, N., Agatsuma, Y., Matsuura, M., Inoue, T., Tomioka, Y., Mizugaki, M., 2002. A simultaneous LightCycler detection assay for five genetic polymorphisms influencing drug sensitivity. Clin. Biochem. 35, 35-40.

Kotetishvili, M., Stine, O.C., Chen, Y., Kreger, A., Sulakvelidze, A., Sozhamannan, S., Morris, J.G. Jr., 2003. Multilocus sequence typing has better discriminatory ability for typing Vibrio cholerae than does pulsed-field gel electrophoresis and provides a measure of phylogenetic relatedness. J. Clin. Microbiol. 41, 2191-296.

Lee, J.H., Han, K.H., Choi, S.Y., Lucas, M.E., Mondlane, C., Ansaruzzaman, M., Nair, G.B., Sack, D.A., von Seidlein, L., Clemens, J.D., Song, M., Chun, J., The Mozambique Cholera Vaccine Demonstration Project Coordination Group, Kim, D.W., 2006. Multilocus sequence typing (MLST) analysis of Vibrio cholerae O1 El Tor isolates from Mozambique that harbour the classical CTX prophage. J. Med. Microbiol. 55, 165-170.

Lightner, D.V., Lewis, D.H., 1975. A septicemic bacterial disease syndrome of penaeid shrimp. Mar. Fish. Rev. 37, 25-28.

Lobitz, B., Beck, L., Huq, A., Wood, B., Fuchs, G., Faruque, A.S., Colwell, R., 2000. Climate and infectious disease: use of remote sensing for detection of Vibrio cholerae by indirect measurement. Proc Natl Acad Sci U S A. 97, 1438-1443. 
Mermoud, I., Costa, R., Ferré, O., Goarant, C., Haffner, P., 1998. Syndrome 93 in New Caledonian outdoor rearing ponds of Penaeus stylirostris: history and description of the three major outbreaks. Aquaculture. 164, 323-335.

Mumy, K.L., Findlay, R.H., 2004. Convenient determination of DNA extraction efficiency using an external DNA recovery standard and quantitative-competitive PCR. J. Microbiol. Methods. 57, 259- 268.

O'Shea, Y.A., Reen, F.J., Quirke, A.M., Boyd, E.F., 2004. Evolutionary genetic analysis of the emergence of epidemic Vibrio cholerae isolates on the basis of comparative nucleotide sequence analysis and multilocus virulence gene profiles. J. Clin. Microbiol. 42, 4657-4671.

Oakey, H.J., Owens, L., 2000. A new bacteriophage, VHML, isolated from a toxinproducing strain of Vibrio harveyi in tropical Australia. J. Appl. Microbiol. 89, 702709.

Overbergh, L., Giuletti, A., Valckx, B., Decallonne, B., Bouillon, R., Mathieu, C., 2003. The use of real-time reverse transcriptase PCR for the quantification of cytokine gene expression. J. Biomol. Tech. 14, 33-43

Panicker, G., Myers, M.L., Bej, A.K., 2004. Rapid detection of Vibrio vulnificus in shellfish and gulf of Mexico water by real-time PCR. Appl. Environ. Microbiol. 70, 498-507.

Rañoa, D.R.E., Hedreyda, C.T., 2005. Sequence analysis of partial toxR gene from Philippine Vibrio isolates and design of toxR-targeted primers for detection. J. Gen. Appl. Microbiol. 51, 343-351.

Saulnier, D., Haffner, P., Goarant, C., Levy, P., Ansquer, D., 2000. Experimental infection models for shrimp vibriosis studies : a review. Aquaculture, 191:133-144.

Thompson, J.D., Higgins, D.G., Gibson, T.J., 1994. CLUSTAL W: improving the sensitivity of progressive multiple sequence alignment through sequence weighting, position specific gap penalties and weight matrix choice. Nucleic Acids Res. 22, 4673-80.

Urwin, R., Maiden, M.C.J., 2003. Multi-locus sequence typing: a tool for global epidemiology. Trends Microbiol. 11, 479-487.

Vernel-Pauillac, F., Falcot, V., Whiley, D., Merien, F., 2006. Rapid detection of a chromosomally mediated penicillin resistance-associated ponA mutation in Neisseria gonorrhoeae_using a real-time PCR assay. FEMS Microbiol. Lett. 255, 66-74

Whalley, S.A., Brown, D., Teo, C.G., Dusheiko, G.M., Saunders, N.A., 2001. Monitoring the Emergence of Hepatitis B Virus Polymerase Gene Variants during Lamivudine Therapy Using the LightCycler. J. Clin. Microbiol. 39, 1456-1459. 
Table 1: Vibrio nigripulchritudo strains

\begin{tabular}{|c|c|c|c|}
\hline Strain name & Date of isolation & context & $\begin{array}{l}\text { Virulence } \\
\text { to } L \text {. } \\
\text { stylirostris }\end{array}$ \\
\hline CIP $103195^{\top}$ & & nigripulchritudo type strain, oceanic waters & $\mathrm{N}$ \\
\hline AM102 & May 1995 & Syndrome 93, moribund shrimp hemoculture & $\mathrm{V}$ \\
\hline AM 115 & May 1995 & Syndrome 93, moribund shrimp hemoculture & $\mathrm{V}$ \\
\hline SO65 & May 1995 & Syndrome 93, moribund shrimp hemoculture & $\mathrm{V}$ \\
\hline SFn1 & March 2000 & Summer syndrome, moribund shrimp hemoculture & $\mathrm{V}$ \\
\hline SFn27 & December 2000 & Sediment pore water, diseased pond & $\mathrm{V}$ \\
\hline SFn115 & March 2002 & Lagoon water in front of pumps, diseased farm & $\mathrm{N}$ \\
\hline SFn118 & April 2002 & Lagoon water in front of pumps, diseased farm & $\mathrm{N}$ \\
\hline SFn135 & December 2002 & Growout pond water, diseased pond & $\mathrm{V}$ \\
\hline AgMn1 & October 2003 & Healthy shrimp hemoculture, before disease outbreak & $\mathrm{N}$ \\
\hline POn3 & April 2002 & Healthy shrimp hemoculture, healthy pond 3 , healthy farm & $\mathrm{V}$ \\
\hline POn4 & April 2002 & Healthy shrimp hemoculture, healthy pond 6 , healthy farm & $\mathrm{N}$ \\
\hline POn12 & December 2002 & Healthy shrimp hemoculture, healthy pond 4 , healthy farm & $\mathrm{N}$ \\
\hline POn13 & December 2002 & Healthy shrimp hemoculture, healthy pond 4 , healthy farm & $\mathrm{N}$ \\
\hline POn19 & January 2003 & Healthy shrimp hemoculture, healthy pond 4 , healthy farm & $\mathrm{V}$ \\
\hline AMn3 & March 2003 & Moribund shrimp hemoculture, opportunistic vibriosis & $\mathrm{V}$ \\
\hline Wn1 & January 2001 & Moribund shrimp hemoculture, opportunistic vibriosis & $\mathrm{V}$ \\
\hline Wn3 & January 2001 & Moribund shrimp hemoculture, opportunistic vibriosis & $\mathrm{V}$ \\
\hline Wn13 & November 2002 & Moribund shrimp hemoculture, opportunistic vibriosis & $\mathrm{V}$ \\
\hline Fn2 & February 2003 & Healthy shrimp hemoculture, healthy pond, healthy farm & $\mathrm{N}$ \\
\hline AQn1 & March 2003 & Healthy shrimp hemoculture, healthy pond, healthy farm & $\mathrm{V}$ \\
\hline BLFn1 & March 2001 & Moribund shrimp hemoculture, opportunistic vibriosis & $\mathrm{V}$ \\
\hline ENn2 & June 2000 & Healthy shrimp hemoculture, healthy broodstock & $\mathrm{V}$ \\
\hline SVn3 & February 2003 & Healthy shrimp hemoculture, healthy farm & $\mathrm{N}$ \\
\hline
\end{tabular}

Bold: Isolates from farms which are affected by the Summer Syndrome. strains.

Italics: Isolates collected during surveys specifically dedicated to the isolation of $\underline{V}$. nigripulchritudo

Virulence: $V$ stands for virulent and $\mathrm{N}$ for Non-virulent (data from Goarant et al., 2006a).

Letters in strain names spells for the isolation farms, i.e. same letters indicate same farm. 


\section{Phylogenetic tree gyrB (673bp)}

Neighbour joining method, Kimura 2 parameters

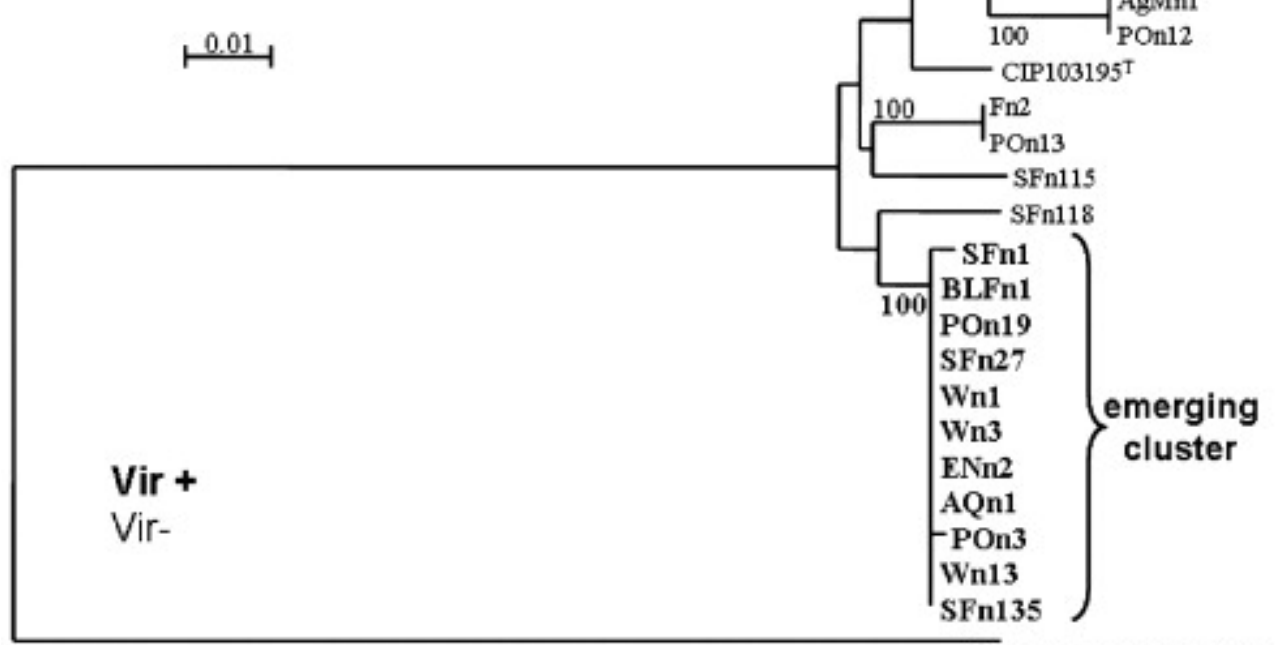

Vibrio penacicida AM101

Figure 1: Dendrogram drawn from gyrB sequences alignment over a selection of $V$. nigripulchritudo strains evidencing the emerging cluster of pathogenic strains. 

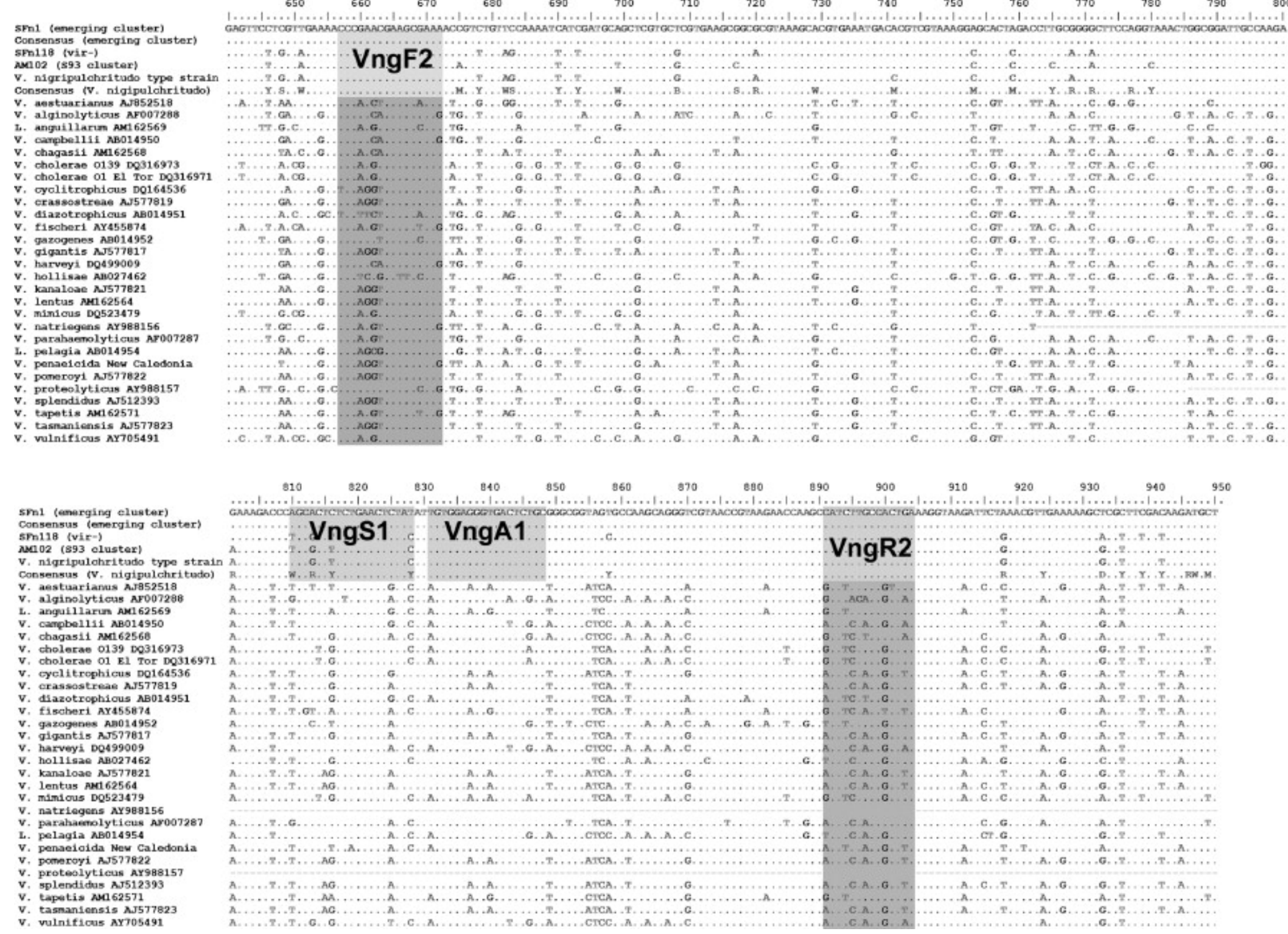

Figure 2: Sequence alignment and position of primers and probes. 

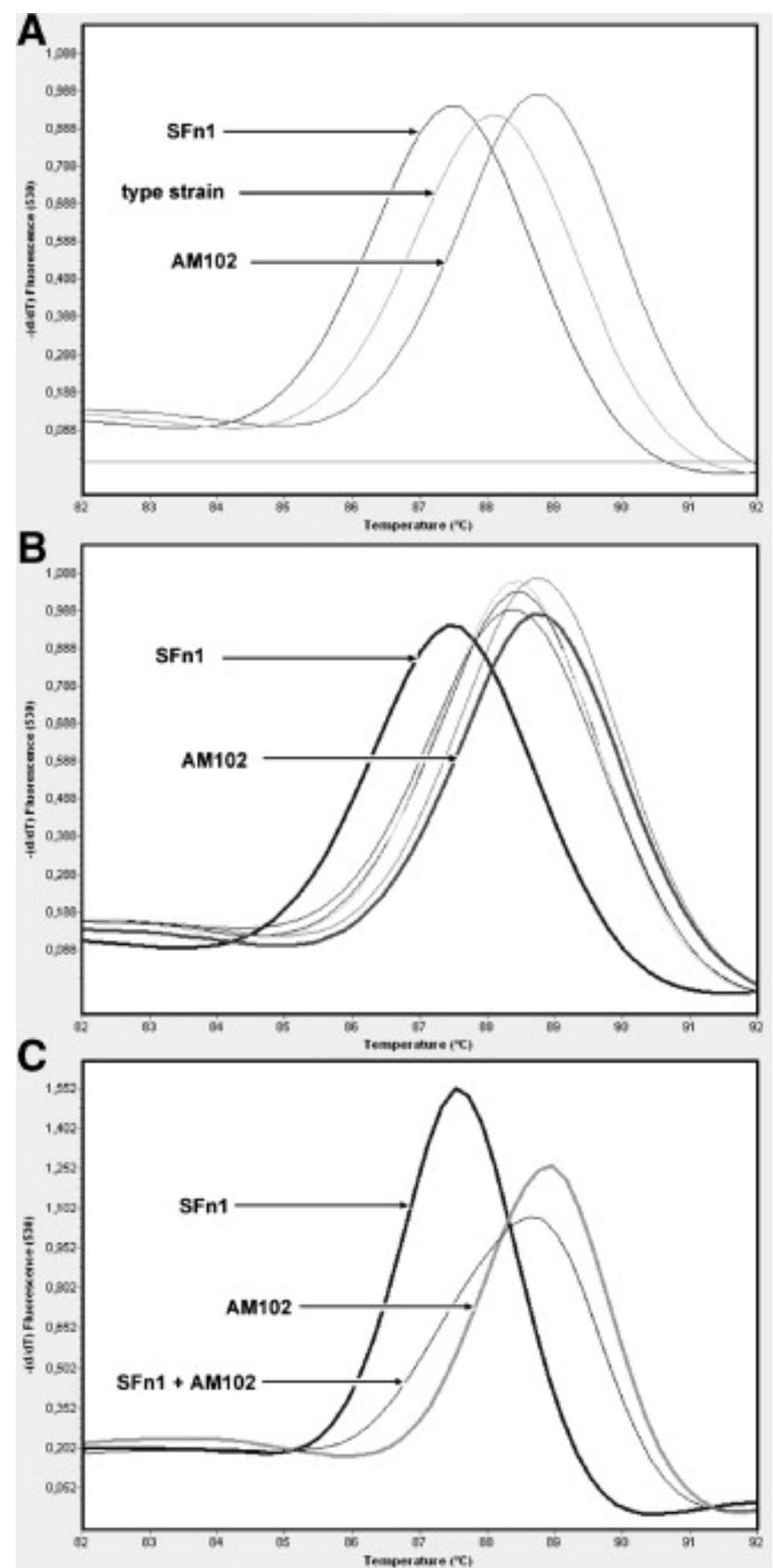

Figure 3: Melting peaks of $V$. nigripulchritudo SFn1 (emerging cluster), AM102 (Syndrome 93) (bold lines) together with type strain (A) non-virulent strains from various origins AgMn1, Fn2, POn4, SFn115 (B) equal quantities of SFn1 and AM102 DNAs mixed as template(C). 

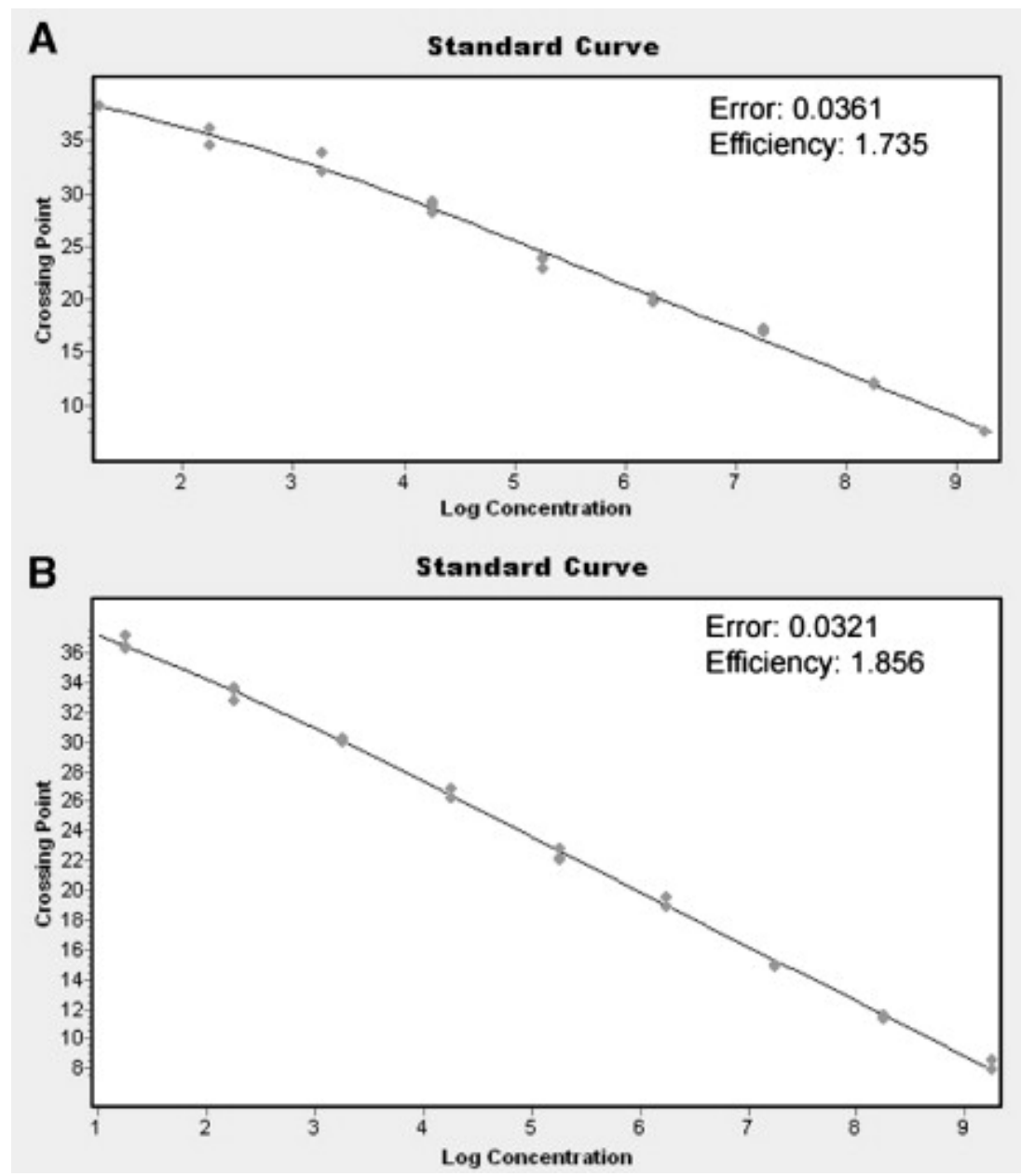

Figure 4: Standard curves obtained with the SYBR Green I assay (A) and the hybridization probe format (B)

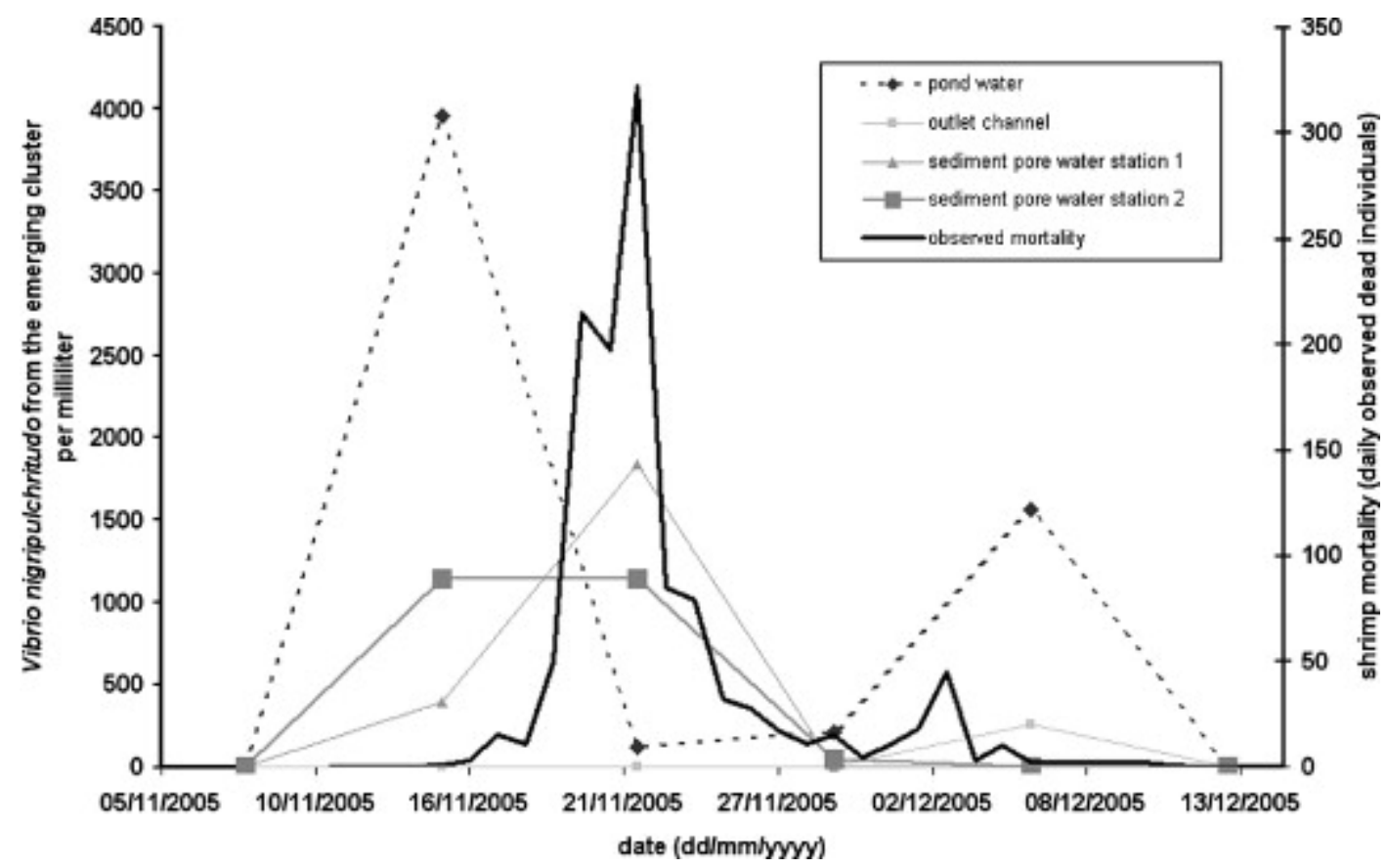

Figure 5: Detection of $V$. nigripulchritudo from the emerging cluster and Summer Syndrome mortality during the survey of an affected pond. 